\title{
Development and prioritization of socio-economic strategies to elevate public participation in natural resource management using TOPSIS approach; Case Study: Chaharmahal and Bakhtiari Province (Iran)
}

\section{*11EBRAHIM, KARIMI SANGCHINI, ${ }^{2}$ IMAN, ISLAMI, ${ }^{3}$ ASGHAR, FARAJOLLAHI; ${ }^{4}$ SEYED ABDOLHOSSEIN ARAMI, ${ }^{5}$ MEISAM JAFARI}

\author{
1 and 5 Department of Environment, Najafabad Branch, Islamic Azad University, Najafabad, Iran, and Human Environmental and \\ Sustainable Development Research Center, Najafabad Branch, Islamic Azad University, Najafabad, Iran \\ 2, 3 4. Department of Arid Zone Management. Gorgan University of Agricultural Sciences and Natural Resources, Gorgan, Iran. \\ Corresponding author: e.karimi64@gmail.com
}

\begin{abstract}
Proper implementation of the participatory projects to conserve national natural resources has become much more important over the recent decades. This socio-economic research seeks developing effective strategies to increase public participation in experts' opinions of Chaharmahal and Bakhtiari Province (Iran), in order to achieve sustainable and integrated management of natural resources. In the first step, the literature review led to the identification of 57 social parameters influencing public participation in the province. In the second step, from the parameters identified, with the help of the Delphi technique, 15 parameters were finalized by experts. This led to the formulation of the effective socioeconomic strategies in the study area. The next step was to prioritize these parameters. For this purpose, the Technique for Order Preference by Similarity to Ideal Solution (TOPSIS) was used in Topsis solver software. The study's statistical population was comprised of the executive experts of Chaharmahal and Bakhtiari Province. The results of the prioritization indicated that the strategy of "the development of alternative livelihoods (A6)" ranks first with normal weight of 0.31 , followed by "focus on profitable projects (A2)" with the normal weight of 0.2 , and "strengthening social cohesion and trust (A7 )" with the normal weight of 0.12 , as the most important strategies to increase public participation. The results of this study can be used by managers and executive decision-makers to protect natural resources and increase feasibility of management activities in Chaharmahal and Bakhtiari Province. OJASEM
\end{abstract}

https://dx.doi.org/10.4314/jasem.v21i3.8

Keywords: Strategies effective on public participation, Delphi technique, Executive experts, TOPSIS, Chaharmahal and Bakhtiari Province.

Environment and natural resources management are the main responsibilities of regional organizations and planning agencies in most countries of the world. Due to the complexity and multi-dimensional nature of the ecosystem, integration of watershed hydrological and socio-economic systems with the aim of the management of natural resources, requires collaborative efforts of beneficiaries and by including the feedbacks from various stakeholders in the decision-making process (Voinov et al. 2008).

Multiple failures in natural resources management projects due to lack of participation by beneficiaries, reflects the importance of their participation in the management plans. Effective public participation can be expected if a match exists among people's needs and project objectives (George, 1992). One of the key points in the management of water and soil resources is the mutual understanding of the interactions between people and natural resources, in order to realize the objectives of improving people's welfare and environmental sustainability for future generations (Cinderby et al. 2011).

Effects of management plans in the provision of the needs of villagers and beneficiaries as well as their role in approving and specifying the project elements, determine the relevance and effectiveness of public participation in the project's success. In the idea of Falconer et al. (1989), the public support and involvement of local communities should be considered in the implementation of management plans. Rural planning and management process needs to achieve a balance between the influential powers in managing the village; the process which is known as participatory management. In the participatory management, all participatory activities are considered in various designing sectors (Krywkow 
and Hare 2008). Lack of understanding the different aspects of economic and social structure of the watershed communities, leads to failure to achieve the anticipated goals and creates a gap between the interests of the state and the people. In other words, in protecting and restoring natural resources, planning, policy development and decision-making will be fruitless without the involvement of people (Johnson et al. 2001).

Collaboration and consultation with stakeholders is one of the key factors in the problem definition phase and participatory modeling (Chan et al. 2008). Participatory modeling and collaborative involvement of stakeholders at various stages of models development and data analysis, is an effective solution to decision-making under difficult circumstances (Voinov et al. 2008), in which public participation is a major factor in the success of the comprehensive evaluation (Newham et al. 2006). Esther and Ndalahwa (2003) believe that the factors affecting public participation in water resources management are influenced by the use of knowledge, experience and ideas of local communities. Garforth et al. (1988), introduced the socio - economic factors as the ones influencing participation of stakeholders in management plans. Chan et al. (2008) suggest that desire and motivation for public participation in natural resource projects, is subject to the tangibility of the projects results to influence their livelihood in a positive direction.

Some of the factors affecting public participation in natural resource projects, include enabling influential peoples such as councils, village administrators and the elders (okoba 2005, Chen et al. 2005, Blomley, 2006, Wani et al. 2008, Folhes et al. 2015, RuizMalle'n et al., 2015 and Palacios et al. 2015), enabling NGOs (Altieri 2002, Chen et al. 2005, Farrington and Lobo, 2008, Wani et al. 2008, Folhes et al. 2015, Palacios et al. 2015 Ruiz-Malle'n et al. 2015), governmental support mechanisms and policy making including financial support and extension policies (Thompson, 1995; Chen et al. 2005, Blomley 2006, Wani et al. 2008, Ruiz-Malle'n et al. 2015), the economic situation of residents of the village due to the natural resources projects (Chen et al. 2005, Blomley, 2006, Wani et al. 2008) and facilities (Chebaane, 2004, Gurung et al. 2005, Okoba, 2005).
Since determining the obstacles and ranking factors will lead to more efficient management; arrangements and alignment of executive measures and guidelines; preventing financial loss and accelerating the realization of reliable results, the use of multi-criteria decision making techniques (MCDM) has been expanded due to their remarkable evaluation, selection and decision-making capabilities. Among the numerous models, TOPSIS was considered, as it ranks the alternatives based on their positive and negative distance to the ideal solution (Ertugrul and Karakasoglu, 2007). This method is regarded adaptive, given that the solutions with the least and greatest distance to the positive and negative ideal solutions are selected.The purpose of this research was to develop and prioritize strategies for effective public participation in views of the experts of the departments in Chaharmahal and Bakhtiari Province, in order to achieve sustainable and integrated management of natural resources. This method can be used for more efficient implementation of the natural resources projects in this deprived province which enjoys rich natural resources.

\section{MATERIALS AND METHODS}

Chaharmahal and Bakhtiari Province with an area of 16533 square kilometers lies over the central plateau of Iran and along the Zagros mountain ranges, between 49.49 and $51.34 \mathrm{E}$ and 31.14 to $32.47 \mathrm{~N}$ in the southwest of the country. Shahrekord is its provincial capital located at $2066 \mathrm{~m}$ above the sea level. Its minimum height is 800 meters above sea level at the outlet of the watershed at the confluence of the River Karun and Khersan and its maximum height is 4548 meters at the rim of the Mount Zard Koh. From the total area of 140000 hectare, $86.6 \%$ is devoted to the forest and rangelands from which $30700(22 \%)$ ha is covered with forests and 1093000 ha $(78 \%)$ with rangelands. The province comprises $1 \%$ of the land area and $10 \%$ of water resources of the country. The Mount Zardkoh is the main source of the three rivers namely Karun, Dez and Zayanderood. These three rivers have historically been the cradle of ancient civilizations and quenched the thirst of the central parts of Iran. The maximum annual rainfall is $1800 \mathrm{~mm}$ decreasing to $300 \mathrm{~mm}$ to the northern and eastern regions of the province. 


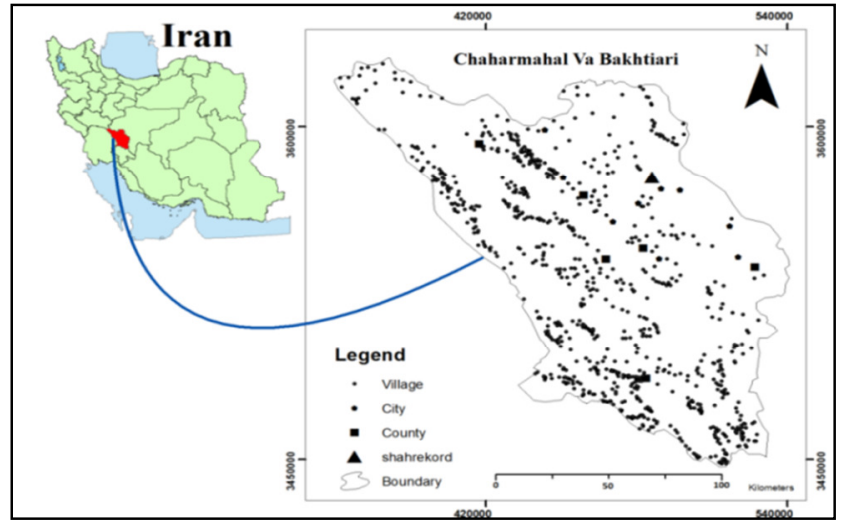

Fig. 1: The location of the Chaharmahal and Bakhtiari province in Iran

Delphi technique: The Delphi method was developed by Project RAND during the 1950s by Olaf Helmer, Norman Dalkey (Dalkey and Helmer, 1963). The aim of Delphi, as initially thought, is to develop a method by the expert opinion, so that long-term trends related to potential future military progresses in science, technology and political affairs be predicted (Jeffery and Hache, 1995). Delphi iterative process involves normally three to four stages, and a series of questionnaires each based on the results of the previous round to select and combine experts' judgments on a real issue (Gordon, 1992). The results of each stage are collected and returned to participants. Participants during successive iterations are able re-evaluate their responses to the compilation of all answers of the participants. Answer sheets are structured anonymously. Participants are known to researchers, but not necessarily to other participants. Anonymity of the participants, ensures that voting is not influenced by the ideas expressed by other participants (Somerville, 2007).

Preliminary selection of the factors influencing public participation: In order to achieve the results and findings of related scientific articles, and to access the latest research findings with the aim of updating the information related to the determinants of public participation in natural resource conservation projects, information needed for research was obtained by searching the internet and by browsing and library resources. To do this research, firstly a review of the library sources was needed in order that all factors affecting public participation natural resources conservation projects be extracted. At this stage, 57 factors and effective strategies were identified. After identifying the factors, Delphi technique and interviews with the experts at the department of Natural Resources of Chaharmahal and Bakhtiari Province were applied to prioritize these factors. In this technique, the opinions put forward by 15 expert were used. After analyzing the results of this phase, 15 most important strategies in public participation in natural resource projects in Chaharmahal and Bakhtiari Province were identified. In Table 1 the most effective factors for the public participation is given.

Population and sample selection procedure: Statistical population is the population of the area, from which it is attempted to select a representative sample. Population should be defined in a way that from the spatial and temporal manner, include all units in the population, and avoid the inclusion of units that should not be addressed in the study (Barran and Jantunen, 2004). Population of this study is comprised of the experts at the natural resources conservation department of the Chaharmahal and Bakhtiari Province who are proficient in their fields and are aware of the socio-economic and environmental conditions of the area. These experts participated in two phases: one based on the Delphi technique and one based on the TOPSIS technique. Questionnaires and interviews were used to extract expert judgments. The population of the study included 15 experts of the executive departments in Chaharmahal and Bakhtiari Province and urban districts, who had great expertise in their field.

Prioritization of the effective strategies for public participation in natural resources conservation projects in Chaharmahal and Bakhtiari Province: TOPSIS is one of the most popular multi criteria decision making methods (MADM) widely used in real decision making situations which was originally developed by Hwang and Yoon (1981).

Topsis is a subgroup of the adaptive models which is per se a subgroup to the compensation models. In the compensation models, there are trade-offs between the strategies, meaning that the weakness of a strategy may be offset by other strategies' scores. In TOPSIS model, the best option is a subjective option, 
determining the preference or suitability of any value or specification. Hwang and Yoon (1981) provided a technique for the best alternative selection, analogous to the ideal solution method. This means that the ideal alternative should have the shortest distance from the positive ideal solution and the farthest distance from the negative ideal solution at the same time (Hwang and Yoon, 1981).

Table 1: The formulation of the strategies affecting public participation in natural resource management projects in Chaharmahal and Bakhtiari Province, extracted from the Delphi technique

\begin{tabular}{|c|c|c|c|}
\hline No & final effective parameters & The formulation of the most important strategies & source \\
\hline 1 & Cooperative approach to public participation projects & Assignment of projects to cooperations & $\begin{array}{c}\text { Gezon, } 1997 ; \text { ECDPM, } \\
2004\end{array}$ \\
\hline 2 & $\begin{array}{l}\text { Paying attention to the profitability and added value of } \\
\text { participatory projects for the beneficiaries }\end{array}$ & $\begin{array}{l}\text { Focusing on the implementation of profitable } \\
\text { projects }\end{array}$ & $\begin{array}{l}\text { O'Faircheallaigh, 2010; } \\
\text { Islami et al., } 2013\end{array}$ \\
\hline 3 & $\begin{array}{l}\text { Regarding the teaching and learning of people and } \\
\text { changing their attitude towards participatory projects }\end{array}$ & Changing public attitudes based on training & $\begin{array}{l}\text { Bond, 2014; } \\
\text { Barkan,1999 }\end{array}$ \\
\hline 4 & $\begin{array}{l}\text { Aligning the objectives of the people and experts in } \\
\text { participatory projects }\end{array}$ & $\begin{array}{l}\text { Aligning the objectives of the people and } \\
\text { designers }\end{array}$ & George, 1992 \\
\hline 5 & Motivational policy formulation for public participation & formulation of motivational policies & George, 1992 \\
\hline 6 & $\begin{array}{l}\text { Capacity building and creating alternative livelihoods } \\
\text { for the exploitation of natural resources }\end{array}$ & $\begin{array}{l}\text { Development of alternative livelihoods } \\
\text { (Modification of life-styles) }\end{array}$ & Hill, 2002; \\
\hline 7 & $\begin{array}{l}\text { Strengthening social cohesion and trust between the } \\
\text { various stakeholders of natural resources }\end{array}$ & Strengthening social cohesion and trust & $\begin{array}{l}\text { Marshall, 2004; Arnold } \\
\text { and Gimenez, } 2007\end{array}$ \\
\hline 8 & $\begin{array}{l}\text { realizing the importance of indigenous knowledge in } \\
\text { efficient management of natural resources }\end{array}$ & $\begin{array}{l}\text { utilization of the high capacity of indigenous } \\
\text { knowledge (using local forces and technology) }\end{array}$ & $\begin{array}{l}\text { Grenier, 1998; Warren \& } \\
\text { cashman ,1988 }\end{array}$ \\
\hline 9 & $\begin{array}{l}\text { Utilization of local stakeholders' capacity in the } \\
\text { formulation, implementation and evaluation of natural } \\
\text { resources }\end{array}$ & Planning based on public opinion & $\begin{array}{l}\text { Falconer, 1987; George, } \\
1992\end{array}$ \\
\hline 10 & Regarding the values, culture and local customs & Strengthen the values, culture and local customs & Goodwin, 1998 \\
\hline 11 & The utilization of modern science and technologies & Utilization of modern technologies & $\begin{array}{c}\text { Ajayi, 2001; McCorckle, } \\
1994\end{array}$ \\
\hline 12 & law enforcement and passing inhibitory laws & passing inhibitory laws & Islami et al., 2013 \\
\hline 13 & Strengthening NGOs and spontaneous movements & $\begin{array}{l}\text { The development of a coherent public } \\
\text { organizations (establishing and strengthening } \\
\text { NGOs) }\end{array}$ & $\begin{array}{l}\text { Findeis, J.L., 1986; Hill, } \\
2002\end{array}$ \\
\hline 14 & $\begin{array}{l}\text { Formulation of insurance policies and supporting for } \\
\text { the beneficiaries of natural resources }\end{array}$ & The development of the insurance system & Sekhar, 2003 \\
\hline 15 & $\begin{array}{l}\text { The development of socio-economic equality between } \\
\text { the various stakeholders }\end{array}$ & The development of socio-economic equality & FAO, 1989 \\
\hline
\end{tabular}

From the standpoint of engineering, one approximation is that the option be considered which have minimum distance from the positive ideal solution and maximum distance negative ideal solution (Hu et al., 2016). For example, in Figure 2, option A1 is comparatively in the shortest distance from both positive and negative options but it is difficult to judge whether to select the option. TOPSIS simultaneously evaluates both distances from the positive and negative ideal solutions by taking the relative closeness to the ideal solution.

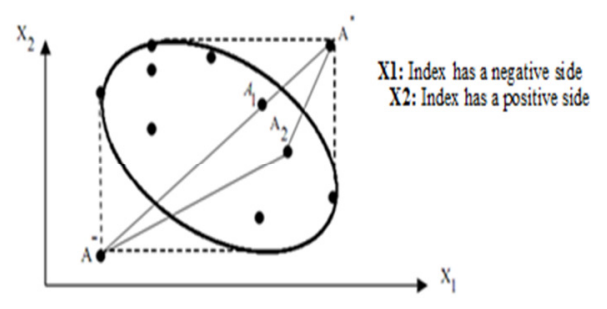

Fig 2: Euclidean distance of the ideal solution and negative ideal solution in a two-dimensional space

In fact, TOPSIS is a robust decision-making method using quantitative and qualitative criteria for prioritization by the similarities and adjacency to the ideal solution. Thus, the alternative must have the shortest distance from the ideal solution. This method is useful when encountering several qualitative and quantitative factors. Existence of overlaps between some of the criteria in this method does not interfere with the logic of the projects and its conclusions. TOPSIS takes into account a set of criteria and their corresponding information. 
The solution depends on the weighting scheme that is given by the decision-maker. Fortunately, some reliable methods have been identified for evaluating the weights which increase the utility of TOPSIS method.

TOPSIS algorithm: TOPSIS method assesses the decision matrix that contains $\mathrm{m}$ alternatives and $\mathrm{n}$ strategies.

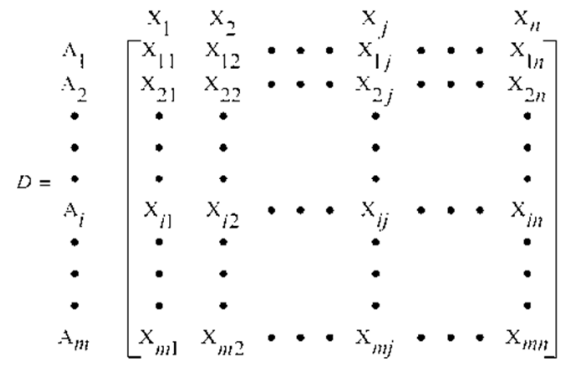

$\mathrm{A}_{\mathrm{i}}: \mathrm{i}^{\text {th }}$ alternative

$\mathrm{X}_{\mathrm{ij}}$ : numerical value obtained from the $\mathrm{i}^{\text {th }}$ alternative with $\mathrm{j}^{\text {th }}$ strategy

In this matrix, the strategy that has monotonically increasing preference (positive side) is a profit strategy, and the strategy that has monotonically decreasing preference (negative side) is considered as the cost strategy. In addition, any results expressed in the decision matrix as parameters need to be quantified, and because the guidelines for the decision-maker (DM) are not of equal importance, a set of weights should be given from the decision maker.

For simplicity, TOPSIS is arranged by a series of successive steps as given:

Step 1- normalization of the decision matrix: The process attempts to standardize the scales given in the decision matrix, so that each value is divided by the size of the vector of the same strategy. Each rij element of normalized decision matrix $\mathrm{R}$ is obtained from the following formula:

$$
r_{i j}=\frac{X_{i j}}{\sqrt{\sum_{i=1}^{m} X_{i j}^{2}}}
$$

Step 2 - weighting the normalized decision matrix: a set of weights $W=\left(w_{1}, w_{2}, \ldots, w_{n}\right)$, where $\sum_{j=1}^{n} w_{j}=1$, is considered by the decision-maker, and by multiplying $j^{\text {th }}$ column of the matrix $R$ with respective $w_{j}$ weight, the weighted normalized decision matrix $\mathrm{V}$ is obtained:

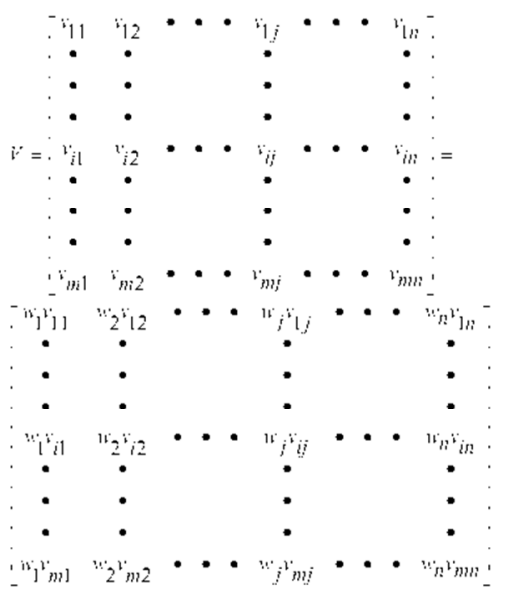

Step 3 - Determination of the ideal solution and negative ideal: two visual options namely $\mathrm{A}^{*}$ and $\mathrm{A}^{-}$are defined as follows:

$A^{\circ}=\left\{\left(\operatorname{Max}_{i} v_{i j} \mid j \in J\right),\left(\operatorname{Max}_{i} \mid j \in J^{\prime}\right) i=1,2, \ldots, m\right\}=\left\{v_{1}^{*}, v_{2}^{*}, \ldots, v_{j}^{*}, \ldots, v_{n}^{*}\right\}$ Positive ideal solution 
$A^{-}=\left\{\left(\operatorname{Max}_{i} v_{i j} \mid j \in J\right),\left(\operatorname{Max}_{i} \mid j \in J^{\prime}\right) i=1,2, \ldots, m\right\}=\left\{v_{1}^{-}, v_{2}^{-}, \ldots, v_{j}^{-}, \ldots, v_{n}^{-}\right\} \quad$ Negative $\quad$ ideal solution

$j \mapsto J=\{j=1,2,3, \ldots, n\}$ J related to profit strategy

$j \mapsto J^{\prime}=\{j=1,2,3, \ldots, n\}$ J related to cost strategy

Two generated virtual options namely $\mathrm{A}^{\circ}$ and $\mathrm{A}^{-}$, are the best (the ideal solution) and least effective alternatives (negative ideal solution).

Step 4. Calculation of the distance: The distance between each n-dimensional option can be measured via Euclidean method. The distance of the $i^{\text {th }}$ option from the positive ideal solution is obtained with the following formula:

$$
i=1,2,3, \ldots, m \quad S_{i *}=\sqrt{\sum_{j=1}^{n}\left(v_{i j}-v_{j}^{*}\right)^{2}}
$$

Similarly, the distance of the $i^{\text {th }}$ option from the negative ideal solution is obtained with the following formula:

$$
i=1,2,3, \ldots, m
$$

$$
S_{i-}=\sqrt{\sum_{j=1}^{n}\left(v_{i j}-v_{j}^{-}\right)^{2}}
$$

Step 5 - proximity of $A_{\mathrm{i}}$ to the $A *$ is defined as follows:

$$
i=1,2,3, \ldots, m
$$$$
0 \prec C_{i *} \prec 1
$$$$
C_{i *}=\frac{S_{i-}}{S_{i *}+S_{i-}}
$$

As can be seen, when $A^{*}=A_{i}$, then $\mathrm{C}_{\mathrm{i} *}=1$ and if $\mathrm{A}^{-}=\mathrm{A}_{\mathrm{i}}$ then $\mathrm{C}_{\mathrm{i} *}=0$

Therefore, higher proximity of the $A_{i}$ to the ideal solution, $A^{*}$ would be closer to the unite value.

Step 6. Ranking the options: Based on the descending order of $\mathrm{C}_{\mathrm{i}^{*}}$ the options can be ranked.

\section{RESULTS AND DISCUSSION}

Using the techniques mentioned in the research methodology and results obtained, the strategic decision matrix was obtained. After generating the matrix, normalized decision matrix was calculated according to the formula 1 . The purpose of establishing normal matrix is to turn the strategies dimensionless. Given the relative importance of each strategy for decision-making, the weights that have been given to the strategies must add up to one. The strategies weights have been obtained based on Delphi technique and questionnaires, distributed among the experts of natural resources services (Table 3). After weighing the strategies, total weights (W) was multiplied in the normalized matrix and the relative proximity to the ideal solution was calculated. Final ranking for two values of relative proximity and the negative ideal solution is always in the same way, but different for positive ideal solution. After taking the abovementioned steps, strategies, ranked in descending order, are given in Table 2 .

According to the table it can be seen that the development of alternative livelihoods strategy (A6) with the normal weight of 0.31 is in the first place and strategies of focusing on profitable projects (A2) and strengthening social cohesion (A7) with the normal weights of 0.2 and 0.12 were respectively the most important priorities for enhancing public participation. Bar graph in figure 3 companies the effective strategies using the obtained weights from TOPSIS model 
Table 2: Ranking of the effective strategies for enhancing public participation in Chaharmahal and Bakhtiari

\begin{tabular}{|c|c|c|c|c|}
\hline No & Developed strategy & $\begin{array}{c}\text { Relative proximity } \\
\text { and the negative ideal solutions }\end{array}$ & $\begin{array}{c}\text { Positive } \\
\text { ideal solutions }\end{array}$ & $\begin{array}{l}\text { Weight of each } \\
\text { strategy (Score) }\end{array}$ \\
\hline A1 & Assigning the project to cooperatives & 7 & 5 & 0.05 \\
\hline A2 & Focusing on profitable projects & 2 & 1 & 0.2 \\
\hline A3 & Changing people's attitudes based on training & 10 & 11 & 0.02 \\
\hline A4 & Align people's goals and designers & 11 & 8 & 0.01 \\
\hline A5 & formulation of Incentive policies & 6 & 6 & 0.05 \\
\hline A6 & Development of alternative livelihoods & 1 & 2 & 0.31 \\
\hline A7 & Strengthening social cohesion & 3 & 4 & 0.12 \\
\hline A8 & utilization of the high capacity of indigenous knowledge & 12 & 13 & 0.01 \\
\hline A9 & project prioritization based on public attitudes & 9 & 12 & 0.02 \\
\hline A10 & Strengthening local values and customs & 8 & 7 & 0.03 \\
\hline A11 & Development of new technologies & 14 & 14 & 0.007 \\
\hline A12 & Enactment of appropriate laws & 13 & 10 & 0.01 \\
\hline A13 & The development of public cohesive organizations & 4 & 3 & 0.09 \\
\hline A14 & The development of the insurance system & 5 & 9 & 0.07 \\
\hline A15 & expanding of socio-economic justice & 15 & 15 & 0.003 \\
\hline
\end{tabular}

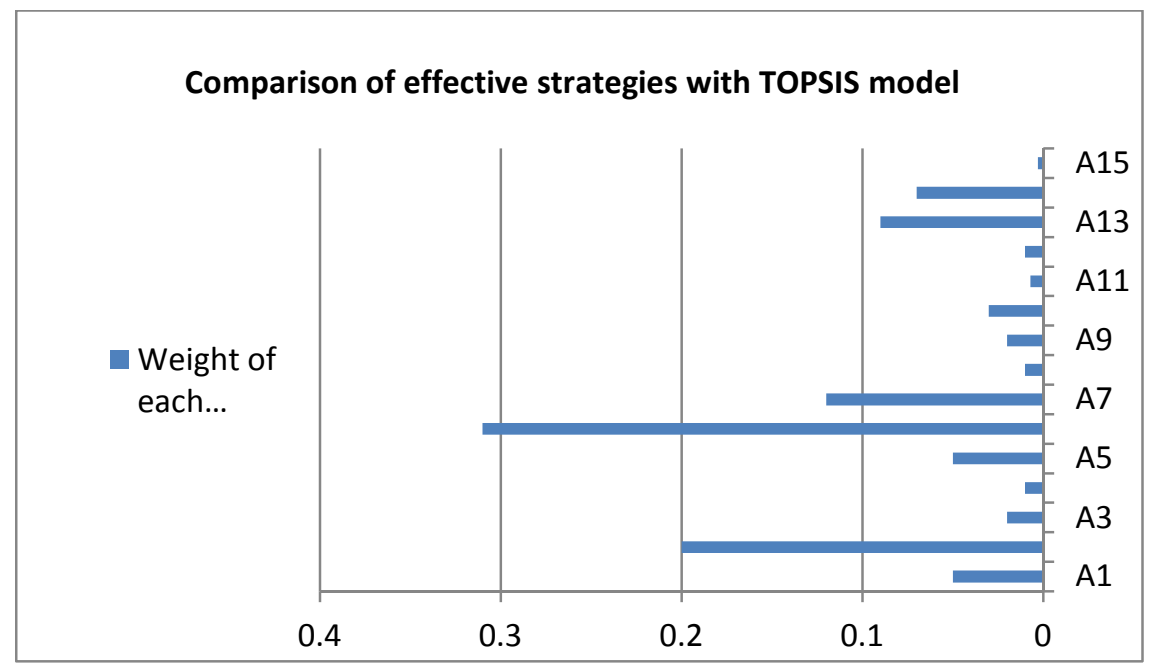

Fig 3: Comparison of effective strategies with TOPSIS model

Conclusion: Natural resource management role in preserving and protecting the natural resources have been taken into consideration in recent years. The identification of the public participation's elements and their interaction has been one of the most important intellectual problems for the researchers in developing countries.

Participatory approach has been created with the aim of improving the human condition, optimizing the use of natural resources, and establishing a logical connection between man and nature, based on four principles: Participation in decision-making, implementation, exploitation of resources, and governance. This type of participation increases public awareness and reduces costs. For public participation, a very important and effective strategy would be the development of alternative livelihoods and focus on profitable projects. In this study, after analyzing the questionnaire data with TOPSIS method, it was found that these two factors are the most effective strategies for participation in natural resource projects in the province. These factors have also been referred to in other studies as the most effective strategy. In this context, research carried out by Thompson (1995), Chen et al. (2005), Blomley (2006), Wani et al. (2008) and Ruiz-Malle'n et al. (2015) could be noted. Perhaps economic incentives are very important for people to participate in the projects, which is consistent with the evaluation of the factors affecting public participation in this study. These results bolds the role of economic stimulus for public participation. Of course, if it is solved based on the TOPSIS positive ideal solution, the place of the two strategies can be changed. This means that the focus on the implementation of profitable projects might be known as the most influential factor. Finally, it is stated that the economic factors are important when it comes to affecting people's participation in Chaharmahal and Bakhtiari province. 
The dependence of the deprived people of the province on natural resources for their livelihood is large and development of alternative livelihoods can reduce the dependency .

In Chaharmahal and Bakhtiari, there is a remarkable capacity for public participation in natural resource projects. By formulating motivational policies one can benefit from these capacities for the improvement of the natural resources. Incentive policies can be in the form of loans, banking facilities and subsidies. The use of incentive policies, and cuts on the taxes and added values increase stakeholders appeal to the natural resources projects in this deprived province. Therefore, they should be given an appropriate place in the administration's policies and strategic plans.

From the perspective of experts in natural resources, strengthening cohesion and trust between the various stakeholders of natural resources, is one of the factors influencing participation, after two factors mentioned above, which shows the importance of unity and solidarity among various stakeholders. This has also been acknowledged in the research conducted by Hill (2002), Ofirchilayegh (2010) and Islami et al. (2013). It seems all the above factors, along with others (natural and human resources) are effective to realize the goals of sustainable development of natural resources in a multi-dimensional manner. Therefore the development as a whole, includes a suite of coordinated efforts: Improving productivity and income of local communities through the development of alternative livelihoods, fundamental transformation of grassroots organizations and strengthening their infrastructure, and changing the attitudes and increasing people motivation in implementing the projects. The results of this study can be used by managers and executive decisionmakers for social and ecological sustainable development in the study area.

\section{REFERENCES}

Ajayi, M. (2001). Evaluation of the effectiveness of extension teaching methods used by agricultural trainees for field days. Journal of extension systems, 17(1), 42-50.

Altieri, M.A. (2002). Agroecology: the science of natural resource management for poor farmers in marginal environments. Agriculture, Ecosystems and Environment, 93, 1-24.

Arnold, J. S., \& Fernandez-Gimenez, M. (2007). Building social capital through participatory research: An analysis of collaboration on Tohono
O'odham tribal rangelands in Arizona, Society and natural resources, 20 (6), 481-495.

Barkan, S. E. (1999). Race, Issue Engagement and Political Participation. Race and Society, 1 (1), 63-76.

Barran, E., \& Jantunen. T. (2004). Stakeholder consultation for Bayesian decision support systems in environmental management. Regional Conference on Ecological and Environmental Modeling (ECOMODE) Penang, Malaysia.

Blomley, T. (2006). Mainstreaming participatori forestry within the local government reform process in Tanzania. International institute for environmental and development, Gatekeeper series, $26 \mathrm{p}$.

Bond, J. (2014). A holistic approach to natural resource conflict: The case of Laikipia county, Kenya, ournal of Rural Studies, 34,) 117 - 127.

Chan, T., Powell, B., Hoverman, S., \& Ross, H. (2008). Participatory approaches in developing a model to assist water resource management in a catchment in the Solomon Islands. International Congress on Environmental Modelling and Software, iEMSs, 850-857.

Chebaane, M., El-Naser, H., Fitch, J.,Hijazi, A. \&Jabbarin, A. (2004). Participatory groundwater management in Jordan: Development and analysis of options. Hydrogeology Journal, 12(1), 14-32.

Chen, Y., Zhang, D., Sun, Y., Liu, X., Wang, N. \& Savenije, H.G. (2005). Water demand management: A case study of the Heihe River Basin in China. Physics and Chemistry of the Earth, 30, 408-419.

Cinderby, S., de Bruin, A., Mbilinyi, B., Kongo, Victor. \& Barron, J. (2011). Participatory geographic information systems for agricultural water management scenario development: A Tanzanian case study. Physics and Chemistry of the Earth, 36, 1093-1102.

Dalkey, N., Helmer, Olaf. (1963). An Experimental Application of the Delphi Method to the use of experts. Management Science, 9 (3), 458-467.

Ertugrul, I., \& Karakasoglu, N. (2007). Performance evaluation of Turkish cement firms with fuzzy analytic hierarchy process and TOPSIS methods. 
Journal of Expert Systems with Applications, 36, 702-715.

Esther, W., \& Ndalahwa, F. (2003). Public participation in integrated water resources management: the case of Tanzania. Physics and Chemistry of the Earth, 28, 1009-1014.

European Centre for Development Policy Management (ECDPM). (2004). Institutional Development: Learning by Doing and Sharing Approaches and tools for supporting institutional development, Netherlands Ministry of Foreign Affairs, Poverty Policy and Institutional Development Division (DSI/AI), 1-15.

Falconer, J. (1987). Forestry extension: A review of the key issues. ODI Social Forestry Network Paper 4e. Overseas Development Institute, NO: 40, London,'UK.

Falconer, J. 1989. Forestry extension: A review of the key issues. Network Paper, Social Forestry Network Uk: Overseas Development Institute. No: 40.

FAO. (1989). Structural Adjustment Programmes in Sub-Saharan Africa, Training Materials for Agricultural Planning no. 15, Rome, 1989.

Farrington, J., \& Lobo, C. (1992). Scaling up participatory watershed development in India: Lessons from the Indo-German watershed development programme. ODI Natural Resource Perspectives, 17,1-17.

Findeis, J.L. (1986). Rural Industrialization: Issues and the Role of Development Typologies, Paper Presented at Rural People and Places: A Symposium on Typologies, Gainsville, PA., Available from Agricultural Economics and Rural Spciology, Pennsylvania State University, University Park.

Folhes, R.T., Aguiar, A.D., Stoll, E., Dalla-Nora, E.L., Araújo, R., Coelho, A., \& Canto, O. (2015). Multi-scale participatory scenario methods and territorial planning in the Brazilian Amazon. Futures, 73, 86-99.

Garforth, C., Van Schoot, C., \& Maarse, L.( 1988). The role of extension in developing the use of rangelands. Agricultural Administration and Extension. 30, 325-334.
George, S. (1992). Generalization in rural development: eleven villages in south Gujarat. Journal of International Development. 18, 43762.

Goodwin, P. (1998). Hired hands or local voice: Understandings and experience of local participation in conservation, Trans Inst $\mathrm{Br}$ Geogr , 23, 481-499

Gordon, T.J. (1992). The methods of futures research [Electronic version].Annals Am Academy Political Soc Sci. 1992, 522: 25-36.

Gurung, T. B., Wagle1, S. K., Bista1, J. D. Dhakal1, R. P., Joshi, P. L., Batajoo, R., Adhikari, P. \& Rai, A. K. (2005). Participatory fisheries management for livelihood improvement of fishers in Phewa Lake, Pokhara, Nepal. Himalayan Journal of Sciences, 3(5), 47-52.

Hill, C. M. (2002). Primate conservation and local communities: Ethical issues and debates. American Anthropologist, 104(4), 1184-1194.

Hu, J., Du, Y., Mo, H., Wei, D., \& Deng, Y. (2016). A modified weighted TOPSIS to identify influential nodes in complex networks Physica A, 444, 73-85.

Hwang, C.L.; Yoon, K. (1981). Multiple Attribute Decision Making: Methods and Applications. New York: Springer-Verlag.

Islami, M. Ghorbani, M. \& Jafari Shalamzari, M. (2013). Identification and prioritization of factors influencing agricultural water price index from farmers' viewpoint in Charkhab Village, Yazd Province. DESERT, 17, 161-167.

Jeffery, G., \& Hache, G.A. (1995). A group-based Delphi application: Defining rural career counseling needs. Measurement Evaluation Counseling Devlp, 28(1), 45-61.

Johnson, N., Ravnborg, H.M., Westermann, O., \& Prodst, K. (2001). User participation in watershed management and research. Journal of Water Policy, 3, 507-520.

Krywkow, J., \& Hare, M. (2008). Participatory process management. International Congress on Environmental Modelling and Software, iEMSs, 888-899. 
Louise, G. (1998). Working with indigenous knowledge (A guid for researchers), published by the International Development research research Centre, po Box 8500 Otawa. On, Canada KIG $3 \mathrm{H} 9$.

McCorckle, C. M. (1994). Farmer Innovation in Niger' Studies in technology and Social Change No. 21. Ames, Iowa: Technology and Social Change program, Iowa state university.

Newham, L.T.H., Jakeman, A.J., and Letcher, R.A. (2006). Stakeholder participation in modelling for integrated catchment assessment and management: An Australian case study. Intl. J. River Basin Management, 4( 3), 1-13.

O'Faircheallaigh, C. (2010). Public Participation and environmental impact assessment: Purposes, implications, and lessons for public policy making. International Journal by Environmental Impact Assessment review, 30, 19-27.

Okoba, B. O. (2005). Farmers' indicators for soil erosion mapping and crop yield estimation in central highlands of Kenya. Wageningen University, Also published as Tropical Resource Management Papers, ISBN 90-8504-157-0, No. 62: $162 p$.

Palacios A. I., Onaindia, M., Potschin, M., Tratalos, J. A. Madariaga, I. \& Haines-Young, R. (2015). Relevance for decision making of spatially explicit, participatory scenarios for ecosystem services in an area of a high current demand. Environmental Science \& Policy, 54, 199-209.

Ruiz-Malle’n, I., Corbera, E., Calvo-Boyero, D. \& Reyes-Garcı́a, V. (2015). Participatory scenarios to explore local adaptation to global change in biosphere reserves: Experiences from Bolivia and Mexico. Environmental Science \& Policy, 54, 398-408.

Sekhar, c.s. (2003). Volatility of agricultural prices_ an analysis of Major international And Domestic markets. Working Paper. no,103. indian Council for research on international economic.

Somerville, J.A. (2007). Critical Factors Affecting the Meaningful Assessment of Student Learning Outcomes: A Delphi Study of the Opinions of Community College Personnel. for the degree of Doctor of Philosophy in Education presented, Oregon State University, 307p.

Thompson, J. (1995). Participatory Approaches in Government Bureaucracies: Facilitating the Process of Institutional Change. World Development, 23( 9), 1521-1554.

Voinov, A., Arctur, D., Zaslavskiy, I., \& Ali, S. (2008). Community-based software tools to support participatory modelling: a vision. International Congress on Environmental Modelling and Software, IEMSs, 766-774.

Wani, S.P., Singh, H.P., Sreedevi, T.K., Pathak, P., Rego, T.J., Shiferaw, B. \& Iyer, S.R. (2003). Farmer-Participatory Integrated Watershed Management: Adarsha Watershed, Kothapally India - An Innovative and Upscalable Approach. SAT eJournal, An Open Access Journal published by ICRISAT, 2(1), 1-26.

Warren, D. M. \& Cashman, K. (1988). Indigenous knowledge for ustainable agricultureand rural development.Gatekeeper series, No. SA 10. London: International Institute for environment. 